\title{
IMPACT OF THE ENVIRONMENTAL LAW DOCTRINE ON THE DEVELOPMENT OF THE STATE ENVIRONMENTAL POLICY AND LAWS
}

\begin{abstract}
Anisimova H. V.
\end{abstract}
\section{INTRODUCTION}

The urgent objective of the modern legal science is to develop a coherent, logically consistent national legal doctrine (and its integral component of environmental law doctrine) as the theoretical basis of the regulation processes, and to form a single legal space and its component of the environmental law space. However, it should be borne in mind that in the EU it was a complex, long-lasting and gradual process, especially in view of the fact that in accordance with the international commitments the common values on the basis whereof the European Union was built, namely democracy, rule of law, respect for human rights and fundamental freedoms, compliance with the standards of the European security system should remain unchanged by virtue of the fact that it is the desire of the Ukrainian society.

The priority of the issue under consideration is confirmed by the theoretical and practical significance of the formulation of such legal categories as "environmental law doctrine", "environmental law", and "state environmental policy" due to which the scientific doctrine of the essence and content of environmental law is expanded, its interaction with other legal branches and sciences not only of legal orientation, the influence on the development of environmental laws in the conditions of sustainable development and European integration processes and the experience of the application thereof, the interpretation of the environmental law rules is improved, and the formation of the modern State Environmental Policy of Ukraine is accelerated. The aforesaid categories contribute to the formation of a legal model of understanding and interpretation of environmental relationship.

It is pertinent to cite V. I. Andreitsev's remarks regarding the fact that scientific doctrines, which are based on the requirements of the applicable environmental laws, tendencies of its improvement and conceptual ideas of some scientific schools, do not take into account the whole range of legislative regulation of environmental relations, which introduces the relevant balance and discipline, the purpose whereof is the formation of 
specialists in the legal profile of different environmental law worldviews and legal thinking ${ }^{1}$.

\section{Environmental law doctrine: scientific approaches to its interpretation}

In the environmental law science (as in all jurisprudence), the term "doctrine" is now widely used. Despite the level and the soundness of the research, there is still not only unanimous opinion on the essence of the concept of "doctrine" and its functions, but also on its place in the system of sources (forms) of law. This, in turn, causes difficulties in the study of the environmental law system, as well as its place in the legal system. We support the conclusions made by Yu. S. Shemshuchenko and A. P. Hetman that the implementation of doctrinal provisions by state construction and legal practice is important for the improvement of law enforcement and, in fact, the legal life of the society, the adaptation of law to modern social and economic and political conditions ${ }^{2}$. According to M. V. Karmalita, legal doctrine, embodying legal ideas, concepts and principles, improves the applicable laws ${ }^{3}$.

Formation of the modern environmental law doctrine (types of concepts) as sector on the defining provisions of legal doctrine (generic concept) is caused by the global environmental crisis related to the depletion of natural resources, pollution of the environment, failure to comply with the requirements of environmental safety in conducting economic activity with waste, etc. In view of all the foregoing, the international community at the end of the twentieth century has chosen a new paradigm for sustainable development, which still remains relevant, and the issue of forming a new international environmental law is not only an increase in the number of environmental agreements, regulations at the national level, but also an improvement in the quality of the national system of environmental laws, which is not perfect. Many of its acts do not meet the current environmental law doctrine, European trends in the development of Ukrainian statehood and the requirements of today.

${ }^{1}$ Правова доктрина України : монографія : у 5 т. Т. 4 : Доктринальні проблеми екологічного, аграрного та господарського права / Ю.С. Шемшученко, А.П. Гетьман, В.І. Андрейцев та ін. ; за заг. ред. Ю.С. Шемшученка. Харків : Право, 2013. С. 97.

${ }^{2}$ Правова доктрина України : монографія : у 5 т. Т. 4 : Доктринальні проблеми екологічного, аграрного та господарського права / Ю.С. Шемшученко, А.П. Гетьман, В.І. Андрейцев та ін. ; за заг. ред. Ю.С. Шемшученка. Харків : Право, 2013. С. 7.

${ }^{3}$ Кармаліта М.В. Правова доктрина - джерело (форма) права : автореф. дис. ... канд. юрид. наук. Київ, 2011. С. 1. 
The scientific and theoretical basis for the study of the legal category "doctrine" is the work of scientists of pre-revolutionary, Soviet and modern periods in various fields of scientific knowledge, concerning theoretical models and concepts, devoted to methodological grounds of legal doctrine, comparative law, theory and philosophy culture, sources of law, including: S. S. Aleksieiev, J. G. Berman, M. I. Baitin, A. I. Bobyliov, S. V. Boshno, A. O. Vasyliev, S. P. Golovatyi, R. David, Yu. A. Zadorozhnyi, O. O. Zozulia, O. S. Ioffe, M. V. Karmalita, D. A. Kerymov, A. A. Kozlovskyi, M. I. Koziubra, M. M. Korkunov, S. I. Maksymov, M. M. Marchenko, M. I. Matuzov, M. E. Mochulska, V. S. Nersesiants, N. M. Onishchenko, N. M. Parkhomenko, I. F. Pokrovskyi, P. M. Rabinovych, I. V. Semenikhin, etc.

The environmental and legal aspects of the development of legal doctrine were the object of study V. I. Andreitsev, H. I. Baliuk, A. H. Bobkova, A. P. Hetman, P. A. Hvozdyk, T. H. Kovalchuk, M. E. Kovalska, V. V. Kostytskyi, S. M. Kravchenko, M. V. Krasnova, P. F. Kulynych, N. R. Malysheva, V. L. Muntian, V. V. Nosik, V. K. Popov, B. H. Rozovskyi, Yu. S. Shemshuchenko, A. S. Shesteriuk, M. V. Shulga, etc.

A significant contribution to the disclosure of the philosophical and legal, methodological and scientific principles of jurisprudence, doctrinal dimensions of the rule of law, human rights, legal system, doctrinal concepts of modern Ukrainian statehood and historical and legal doctrines was made by the collective of authors of the monograph "General Theoretical and Historical Jurisprudence" of the five-volume "Legal Doctrine of Ukraine" . In the "Great Ukrainian Legal Encyclopedia" legal doctrine is regarded as "stipulated by the nature of the legal culture of society a holistic and logically consistent set of ideas and scientific views on the right, which serves as the basis of professional justice and the conceptual basis of rulemaking, law enforcement, and interpretation operations". The legal doctrine is a product of scientific activity, a kind of summary of knowledge of state reality in a specific historical period ${ }^{5}$.

${ }^{4}$ Правова доктрина України : монографія : у 5 т. Т. 1 : Загальнотеоретична та історична юриспруденція / В.Я. Тацій, О.Д. Святоцький, С.І. Максимов та ін. ; за заг. ред. О.В. Петришина. Харків : Право, 2013.976 с.

${ }^{5}$ Велика українська юридична енциклопедія : у 20 т. Т. 3 : Загальна теорія права / редкол.: О.О. Петришин (голова) [та ін.] ; Нац. акад. прав. наук України, Ін-т держави і права ім. В.М. Корецького НАН України ; Нац. юрид. ун-т ім. Ярослава Мудрого. Харків : Право, 2017. С. 471. 
The opinion of H. I. Baliuk that environmental law science is no exception should be supported ${ }^{6}$. At the same time, as noted, the development of science is not only a process of quantitative accumulation of knowledge about any phenomenon, but also an evolutionary transition to the realization of its new quality. As of today, the authors of the section of the monograph "Doctrinal Problems of Environmental, Agrarian and Business Law" of the aforementioned five volumes have applied the most systematic approach to study the doctrine of the modern environmental law of Ukraine in the 20th - 21st centuries. The modern doctrine of environmental law and laws, already presented by scientists ${ }^{8}$, is based on the principles of market economy, European integration processes, achievement of sustainable development for our country, in order to ensure in the environmental law field the priority of human and citizen's rights and freedoms, rule of law, transparency and openness activities of both state and local government authorities and civil society organizations, establishing constructive interaction between them, increasing their responsibility, implementation of the state and regional environmental policies and resolving local issues, etc.

As V. I. Andreitsev notes, scientific legal doctrines were formed and legalized under the existing mechanism of legal regulation with all its progressive and regressive ideas, regulations, and attitudes towards carrying out various activities that would be compatible with the principles of the relevant environmental policy. That is why doctrinal approaches should be adequate to the content of the latter, with certain elements of scientific predictability for the future, since environmental law science is characterized by a predictive function ${ }^{9}$. On the basis

${ }^{6}$ Балюк Г.І. Роль доктрини екологічного права в започаткуванні і розвитку ядерно-правових досліджень в Україні. Правова доктрина України : монографія : у 5 т. Т. 4 : Доктринальні проблеми екологічного, аграрного та господарського права / Ю.С. Шемшученко, А.П. Гетьман, В.І. Андрейцев та ін. ; за заг. ред. Ю.С. Шемшученка. Харків : Право, 2013. Підрозд. 1.7. С. 252.

7 Правова доктрина України : монографія : у 5 т. Т. 4 : Доктринальні проблеми екологічного, аграрного та господарського права / Ю.С. Шемшученко, А.П. Гетьман, В.І. Андрейцев та ін. ; за заг. ред. Ю.С. Шемшученка. Харків : Право, 2013. 848 с.

8 Гетьман А.П. Доктрина екологічного права та законодавства України : монографія. Харків : ТОВ “Оберіг”, 2019. 336 с. (Харківська наукова школа екологічного права).

9 Андрейцев В.I. Інкорпорація як важлива форма систематизації екологічного законодавства. Правова доктрина України : монографія : у 5 т. Т. 4 : Доктринальні проблеми екологічного, аграрного та господарського права / Ю.С. Шемшученко, А.П. Гетьман, В.І. Андрейцев та ін. ; за заг. ред. Ю.С. Шемшученка. Харків : Право, 2013. Підрозд. 1.4. С. 98. 
thereof, V. I. Andreitsev proposed the author's definition of the scientific doctrine of environmental law - a system of logical and consistent scientific provisions, principles of justification and prediction of the scientist (scientists), formulated on the basis of analysis, synthesis, other methods of scientific research, generalizations and conclusions about genesis, the status and development of environmental law and legislation, their constituents and elements (industries, sub-sectors, institutes, super-institutes), which, based on progressive methodological principles, proves (proposes and approves) new scientific approaches to the legal understanding and legal realization of environmental legal relationships or their sectors with respect to the maintenance and guarantee of the legal personality of participants in these legal relationship ${ }^{10}$.

In view of the definition of V. I. Andreitsev, the sector environmental law doctrine is the result of environmental-legal scientific researches based on interdisciplinary approaches to the science of environmental law. As new knowledge, the doctrine acquires the status of scientific under the conditions of compliance with two requirements: scientific validity (authenticity) and formal-logical conformity to the general initial principles and laws of legal science ${ }^{11}$.

Pursuant to Article 8 of the Law of Ukraine "On Environmental Protection" dated June 25, 1991 No. 1264-XII ${ }^{12}$ the systematic complex scientific researches of the environment and natural resources are made in the state for the purpose of developing the scientific bases for the protection thereof and rational use and ensure environmental safety. The results thereof are coordinated and exposed to synthesis by the NAS of Ukraine and the central executive authority, which implements state policy in the field of environmental protection. Furthermore, the grounds for the further development of the modern environmental science are the laws of Ukraine "On Scientific and Technical Operations" dated

${ }^{10}$ Андрейцев B.I. Наукова доктрина - методологія пізнання та удосконалення екологічного права та практики його застосування. Сучасні науково-практичні проблеми екологічного, земельного та аграрного права : матеріали круглого столу (м. Харків, 6 груд. 2013 р.) / за заг. ред. А.П. Гетьмана. Харків : Право, 2013. С. 12.

11 Мочульська М.Є. Правова доктрина в континентальній правовій системі : автореф. дис. ... канд. юрид. наук. Львів, 2011. С. 8.

12 Про охорону навколишнього природного середовища : Закон України від 25.06.1991 № 1264-XII. URL: http://zakon5.rada.gov.ua/laws/show/1264-12 (date of access: 28.01.2020). 
November 26, 2015 No. 848-VIII ${ }^{13}$, “ On Higher Education” dated July 1, 2014 No. 1556-VII ${ }^{14}$, "On Basic Principles (Strategy) of the State Environmental Policy of Ukraine for the period up to 2030 dated February 28, 2019 No. 2697-VIII" ${ }^{15}$, and the Presidential Decree "On the Strategy for Sustainable Development" Ukraine 2020" dated January 12, 2015 , No. $5 / 2015^{16}$ etc. All of the aforesaid acts are aimed at improving and increasing the science level, including the social sciences and humanities, whereas the environmental science is an integral part thereof. The objective of the latter is to develop and systematize the environmental laws by taking into account the influence of social, economic, political and international factors. However, despite the adoption of the Law of Ukraine "On Scientific and Scientific and Technical Operations' dated November 26, 2015 No. 848-VIII ${ }^{17}$, the purpose whereof is to modernize the legislative support of the field of scientific and scientific-technical operations, to provide conditions for increasing the efficiency of scientific research and use the results thereof to ensure the development of all spheres of public life, the implementation of its regulations is extremely slow. Certainly, the Law: a) provides access to research funding not only for specific institutions, but also for teams of scientists and even individual scientists; b) change the whole system of financing such research; c) increase a part of the grant funding, which will be distributed through the National Research Fund of Ukraine ${ }^{18}$; d) grants priorities to the development of research at universities; e) involves the participation of young scientists in the formation of scientific and scientific-technical policy; f) introduces a rule that state scientific institutions and state

13 Про наукову і науково-технічну діяльність : Закон України від 26.11.2015 № 848-VIII. URL: http://zakon5.rada.gov.ua/laws/show/848-19 (date of access: 27.01.2020).

14 Про вищу освіту : Закон України від 01.07.2014 № 1556-VII. URL: https://zakon.rada.gov.ua/laws/show/1556-18 (date of access: 27.01.2020).

15 Про Основні засади (стратегію) державної екологічної політики України на період до 2030 року : Закон України від 28.02.2019 № 2697-VIII. URL: https://zakon.rada.gov.ua/laws/show/2697-19 (date of access: 27.01.2020).

16 Про Стратегію сталого розвитку “Україна-2020” : затв. Указом Президента України від 12.01.2015 № 5/2015. URL: http://zakon2.rada.gov.ua/ laws/show/5/2015 (date of access: 28.01.2020).

17 Про наукову і науково-технічну діяльність : Закон України від 26.11.2015 № 848-VIII. URL: http://zakon5.rada.gov.ua/laws/show/848-19 (date of access: 27.01.2020).

18 Про Національний фонд досліджень України : Постанова Каб. Міністрів України від 04.07.2018 № 528. URL: http://zakon.rada.gov.ua/laws/show/ru/528-2018-\% D0\%BF (date of access: 27.01.2020). 
universities, academies, institutes are entitled to co-founders of companies for the purpose of using the objects of intellectual property rights. However, it is difficult to achieve this quickly, and therefore much remains to be done for the effective operation of this Law.

Since 01.01.2021 the Law of Ukraine "On Fundamental Principles (Strategy) of the State Environmental Policy of Ukraine for the Period up to 2030" came into force, which defines the vectors for reforming modern environmental laws. Undoubtedly, the ambiguous (and in some cases almost negative) attitude to the principles of modern state environmental policy has become well known. It should be noted that in accordance with the resolution of the Verkhovna Rada of Ukraine (dated September 18, 2019), on November 27, 2019, the parliamentary hearings were held on "Priorities of environmental policy of the Verkhovna Rada of Ukraine for the next five years" with the participation of representatives of central and local executive authorities, authorities local self-government, nongovernmental organizations, scientific institutions. Wherein proposals of the Cabinet of Ministers of Ukraine and the Ministry of Energy and Environmental Protection of Ukraine were published (Letters dated 28.10.2019 No. 23973/0/2-19 and No. 5/4-10/11699-19). First of all, it is a matter of submitting to the Verkhovna Rada of Ukraine a number of draft laws of Ukraine. In which, taking into account the processes of globalization and social transformation, urgent measures are proposed. It is proposed to adopt laws: "On the Principles of Monitoring, Reporting and Verification of Greenhouse Gas Emissions"; "On Ozone-Depleting Substances and Fluorinated Greenhouse Gases"; "On Ratification of the Kigali Amendment to the Montreal Protocol"; "On Waste Management"; "On Chemical Safety"; "Ratification of the Nagoya Protocol on Access to Genetic Resources and the Equitable and Equitable Sharing of Benefits from their Use to the Convention on Biological Diversity"; "On the State Biosafety System for the Creation, Testing, Transportation and Use of Genetically Modified Organisms" (revised); "On the Ratification of the Nagoya-Kuala Lumpur Additional Protocol on Liability and Compensation to the Cartagena Protocol on Biosafety"; a new wording of the Subsoil Code; "On Amendments to Some Legislative Acts of Ukraine on Improvement of Environmental Laws", etc.

We should add that now it is required to take into account the fact that the limits of international cooperation, established by the Agreement between Ukraine and the European Community on scientific and technological cooperation, will allow to reach the goal faster - gradual approximation of Ukraine to the EU policy and law in this sphere and 
involvement of our country to the European Research Area, which is also provided for in the Association Agreement between Ukraine, on the one hand, and the European Union, the European Atomic Energy Community and their Member States, on the other hand (hereinafter referred to as - the Association Agreement). In view of all the aforesaid facts, O. O. Orendarets regards the objective of the science of environmental law today in the substantiation of the modern concept and doctrine of the development of environmental law in the conditions of economic and social present, priority directions of legislative activity in this sphere of public relations for the near and distant perspective, systematics in development and adoption of environmental laws in the light of economic, social, international and political challenges ${ }^{19}$. V. I. Andreitsev hereby states in view of the foregoing that environmental-legal science should still precede the creation of scientific doctrines and concepts of the development of environmental laws, the formation of state environmental policy. Certainly, this fact will greatly accelerate the development of the latter, will ensure the adoption of the principles of environmental law in the practice of law, which, so to speak, "owes" it is environmental law, in particular, to determine the scientific approaches and the theoretical and practical provisions of certain scientific law schools ${ }^{20}$.

For the sake of completeness and comprehensive study of the issue, it is important that the formation of doctrines is linked to the creation of scientific schools. In the modern period, according to V. I. Andreitsev, the process of forming the latter is becoming more and more cross-sector, which is explained by the emergence of powerful scientific and coordination centers through the legalization of all-Ukrainian and international scientific structures, the leaders whereof have the opportunity to arrange for the structured mobile scientific teams around the ideas and doctrines that bring together scholars of relevant legal knowledge ${ }^{21}$. Moreover, as he continues and develops this view, S. I. Maksymov emphasizes that universal teachings acquire doctrinal nature only when they are used to solve a particular legal issue, although the aforesaid doctrines (for example, positivism and the theory of natural law, the

19 Орендарець О.О. Розвиток науки екологічного права : автореф. дис. ... канд. юрид. наук. Київ, 2015. С. 3.

${ }_{20}$ Андрейцев В.І. Екологічне право і законодавство суверенної України: проблеми реалізації державної екологічної політики : монографія. Дніпро : Нац. гірн. ун-т, 2011. $373 \mathrm{c}$.

21 Андрейцев B.I. Наукові та науково-практичні школи: стан та перспективи правового регулювання : монографія. Київ : Знання, 2009. С. 21. 
concept of the rule of law - legal states) and formulate their provisions in the abstract, in the most general form ${ }^{22}$.

At the same time, it is worth noting again that legal sources, in particular in scientific works on environmental law, have differences in the understanding of the jurisprudential nature of the doctrine, the interpretation of its essence and features. Under the current conditions in jurisprudence, the legal category "doctrine" operates in a variety of phrases: positivist, natural law doctrine of absolute sovereignty, doctrine of control over crime, doctrine of national security, doctrine of law, state and legal doctrine, legal doctrine, the doctrine (or doctrine of international law), the doctrine of globalization of human and citizen rights, the doctrine of employment, etc., which again confirms the multidimensionality of this term.

It should be noted that any doctrine is based on the idea of the nature of law, of the fact what it is. The basis of such ideas, as noted by S. I. Maksymov, are two opposing intuitions: a) law is a social fact; it is created by power-holders (such as legislators and judges) or by human habits; b) judges and law researchers gain knowledge of it through valuation operations, that is, interpretations of laws, precedents, and other sources of law. Such an interpretation is inevitably linked to justice; therefore, an unfair interpretation is wrong ${ }^{23}$.

Let's recall that the science of environmental law in its evolution has passed several stages. In addition, the achievements made during each of them allow differentiation, separation of legal institutions, sub-sectors and branches of environmental law in the process of their formation. Based on the above, we can say that the evolution of environmental law is a continuous process that reflects the dialectic of environmental relations, although it is uneven, which is due to the development of various fields of knowledge - technical and social. Equally important, however, is that the integration of different spheres of knowledge into environmental law contributes to the creation of scientifically sound environmental law doctrine, lays the foundation for the legal regulation of social relations that ensure environmental rights, environmental law, the harmonious interaction of nature and society and satisfying the interest of the parties subject to the law.

\footnotetext{
22 Андрейцев B.I. Наукові та науково-практичні школи: стан та перспективи правового регулювання : монографія. Київ : Знання, 2009. С. 63.

23 Максимов С.І. Правова доктрина: філософсько-правовий підхід. Правова доктрина України : монографія : у 5 т. / за ред. В.Я. Тація, О.Д. Святоцького, C.I. Максимова [та ін.]. Т. 1 : Загальнотеоретична та історична юриспруденція / за заг. ред. О.В. Петришина. Харків : Право, 2013. Підрозд. 1.3. С. 58-93.
} 
First of all, it is emphasized that various definitions of sources get various definitions of the category "legal doctrine", such as: a) doctrine (theory) as a set of theoretical provisions on legal phenomena; b) state program (concept) of regulation of public relations, setting goals, objectives, determining the means for the implementation thereof; c) a set of general principles, starting principles of law, supported or sanctioned by the state; d) guiding theoretical principles, basic legal definitions; e) scientific works of authoritative researchers; f) the views of legal scholars on particular issues of law-making and enforcement; g) element of the legal system, etc. As we can see, "doctrine" is a complex, comprehensive and multifaceted concept ${ }^{24}$.

The semantic analysis of the term "doctrine" enabled A. O. Vasyliev for concluding that there are two meanings as follows: a) doctrine as a teaching, text, and b) doctrine as a set of ideas supported by scholars. In the context of jurisprudence, legal doctrine means a doctrine of law and ideas endorsed and defended by the corporation. Therefore, there is an understanding of doctrine as a system of principles, perceptions, and views of nature, society and a person.

In philosophical and legal science, the term "doctrine" is usually used in the context of such concepts as "doctrine", "social science", "philosophical theory (natural law, positivist)", "ideology (liberal, socialist, conservative)", "dogma", "concept" and others. However, in all cases, as noted by S. I. Maksymov, in its application refers to the doctrine (knowledge), which is to some extent reduced to the internal consistent nucleus, which is why it is aimed at direct use in practice. General understanding of the concept of "doctrine" in the scope of legal importance acquires its specific manifestation as a legal doctrine ${ }^{25}$.

Let's consider the basic approaches to legal understanding of the category "legal doctrine". First of all, let us start from the point of view of V. V. Kopieychykov, who emphasized that legal doctrine should be considered as a set (system) of scientific knowledge about a certain legal

24 Анісімова Г. В. Вплив природно-правової концепції на розвиток екологоправової доктрини, науки та законодавства. Рівень ефективності та необхідності впливу юридичної науки на нормотворчу діяльність та юридичну практику : матеріали міжнар. наук.-практ. конф. (м. Харків, 5-6 лют. 2016 р.). Харків, 2016. C. 52 .

Максимов С.І. Правова доктрина: філософсько-правовий підхід. Правова доктрина України : монографія : у 5 т. / за ред. В.Я. Тація, О.Д. Святоцького, C.I. Максимова [та ін.]. Т. 1 : Загальнотеоретична та історична юриспруденція / за заг. ред. О.В. Петришина. Харків : Право, 2013. Підрозд. 1.3. С. 60-61. 
phenomenon. It may be developed under the appropriate conditions into a more or less generalized theory of law. The relationship between legal doctrine and legal theory is somewhat relative. If the legal doctrine covers a wide range of fundamentally important methodological issues, it may initiate the development of relevant theories of law. Mostly it is included in the theory of law as its element ${ }^{26}$.

According to N. M. Parkhomenko ${ }^{27}$, T. Ya. Khabrieva ${ }^{28}$, K. V. Romanov $^{29}$ and other jurists, the legal doctrine in its meaning is closest to legal science, and in most cases the terms "science" and "doctrine" are identical, identical terms. Doctrinal provisions are predominantly scientific in nature, but not any science is a doctrine. In legal science there are many concepts, approaches, theories, which offer different approaches (often diametrically opposite in content) to solving certain problems of legal regulation. Scientific pluralism lies in the very principle of scientific rigor. No scientific concept can claim "truth" in the last instance, and therefore presupposes that there are other points of view on the problem under study ${ }^{30}$.

\section{Environmental law doctrine as a source (form) of law}

Scholars are asked more often whether legal doctrine is the source (form) of law. It is well known that the legal systems of the world differ in the originality of sources of law, the degree of their development, the priority of some sources over others. However, in these systems, the sources of law are regulatory acts, regulatory legal agreements, legal customs, judicial precedents (or case law), general principles of law, legal doctrine. Therefore, within the Romano-German legal system, the general principles of law play an important role as an independent source of law ${ }^{31}$.

${ }^{26}$ Міжнародна поліцейська енциклопедія : у 10 т. / відп. ред. Ю.І. Римаренко, Я.Ю. Кондратьєв, В.Я. Тацій, Ю.С. Шемшученко. Т. 1 : Теоретико-методологічні та концептуальні засади поліцейського права та поліцейської деонтології. Київ : Ін Юре, 2003. C. 186.

${ }^{27}$ Пархоменко Н.М. Джерела права: проблеми теорії та методології : монографія. Київ : Юрид. думка, 2008. С. 141.

28 Хабриева Т.Я. Доктринальное значение российской Конституции. Журнал российского права. 2009. № 2. С. 34.

29 Романова Е.В. Судебная доктрина в системе источников налогового права США : автореф. дис. ... канд. юрид. наук. Москва, 2012. С. 4.

30 Семеніхін І.В. Правова доктрина: загальнотеоретичний аналіз / за ред. О.В. Петришина. Харків : Юрайт, 2012. Вип. 2. С. 26.

31 Теорія держави і права : підручник / О.В. Петришин, С.П. Погребняк, В.С. Смородинський [та ін.] ; за ред. О. В. Петришина. Харків : Право, 2014. С. 108. 
According to the jurists (and this is not in dispute), the Ukrainian legal system is referred to this type of legal system as a kind of European form $^{32}$. At the same time, the issues of the number of legal families, their groups, classes and types and their classification have been, and remain, debated. However, in the domestic scientific environment there is a crisis of the methodology of legal positivism, and this has an impact on studies that violate the problem of typology and classification of the legal system of Ukraine.

Law scholars distinguish between two basic, diametrically opposed, contradictory approaches, but this does not preclude their internal differentiation in recognizing or denying the regulatory function of legal doctrine, its ability to be a source of law. The vast majority of experts view the doctrine as a source (form) of law or as a factor that significantly influences law-making and law-enforcement practices ( A. O. Vasyliev, M. M. Voplenko, V. V. Diervoied, O. O. Zozulia, S. A. Karapetian, M. V. Karmalita, T. M. Priakhin, N. M. Parkhomenko, R V. Puzykov, I. V. Semenikhin, V. V. Sorokin, etc.). For example, O. O. Zozulia considers legal doctrine to be a general legal category that integrates a set of legal and scientific interpretations and judgments about positive law, within the scope thereof the legal forms of knowledge of law and legal phenomena, principles, concepts, terms, constructions, methods and techniques are developed and substantiated, means of understanding and interpreting positive law, its sources, systems, structures, actions and applications, violations and restoration ${ }^{33}$.

At the same time, M. V. Karmalita views legal doctrine as a source (form) of law, which contains a system of fundamental views of jurists on state-legal phenomena, scientifically substantiates socially important problems in order to more effectively solve them and outlines the strategic prospects of legal development of the state. The researcher focuses on the shortcomings of a purely positive approach to understanding the concept of "source of law" (for example, its identification with the system of sources of law), which simplified this problem and negated its importance for legal practice ${ }^{34}$. We express our solidarity with her assertion that the

32 See: Скакун О.Ф. Теория государства и права : учебник. Харьков : Консум, 2000. С. 238; Оніщенко Н.М. Правова система: проблеми теорії : монографія. Київ : Ін-т держави і права ім. В.М. Корецького НАН України, 2002. С. 110.

33 Зозуля А.А. Доктрина в современном праве : автореф. дис. ... канд. юрид. наук. Санкт-Петербург : Петербург. гуманитар. ун-т профсоюзов, 2006. С. 10.

34 Кармаліта М.В. Правова доктрина - джерело (форма) права : автореф. дис. ... канд. юрид. наук. Київ, 2011. 21 с. 
use of legal doctrine as a source of law in legal systems and the feasibility of transforming environmental law doctrine into sources of environmental law in the following cases: a) its interpretation; b) development of bills and their adoption; c) implementation of the provisions of the legal doctrine in the resolutions of the constitutional courts, their justification on the basis of the legal doctrine of judicial or administrative resolution according to the formula "in accordance with the thought ruling in the scientific literature" 35 .

Considering the features and perspectives of the development of the system of sources of law, N. M. Parkhomenko emphasizes the need for enhancing the role of legal doctrine in it, ensuring the constant feedback of legal science and practice. In her view, legal doctrine is part of the system of sources of law (its subsystem), but it does not have its own systemic structure $^{36}$. In our opinion, it is advisable to support the position of scholars who consider such a contradiction. Legal doctrine is a complex multi-structural phenomenon, the elements of which are interrelated sector legal doctrines. In the legal scientific literature in this regard, the opinion is expressed about the existence of certain subspecies (levels) of legal doctrine, which should mean sector legal doctrines ${ }^{37}$.

As S. V. Boshno rightly points out, scientific work can become doctrinal if it contains practical recommendations, comments on laws and other forms of law; predicts the processes of lawmaking and legal implementation; eliminates gaps in laws ${ }^{38}$. Other researchers are of the same opinion $^{39}$. Only a part of the scientific provisions acquires signs of

${ }^{35}$ Кармаліта М.В. Правова доктрина - джерело (форма) права : автореф. дис. ... канд. юрид. наук. Київ, 2011. С. 16-17.

${ }^{36}$ Пархоменко Н.М. Система джерел права: ознаки, властивості та зміст. Часопис Київського університету права. 2007. № 3. С. 11-12.

37 Любитенко Д.Ю. Системные свойства правовых доктрин. Вестник Владимирского юридического института. 2011. № 1. С. 140-145; Пузиков Р.В. Юридическая доктрина в сфере правового регулирования (проблемы теории и практики) : дис. ... канд. юрид. наук. Тамбов, 2003. 213 с.; Сорокин В.В. Судебная практика или правовая доктрина. Арбитражный и гражданский процесс. 2002. № 8. С. 8-11; Трофименко В.А. У пошуках ідеального джерела права: правові доктрини світу. Юридичний радник. 2007. № 4 (18). С. 82-88 тощо.

${ }_{38}$ Бошно С.В. Доктрина как форма и источник права. Журнал российского права. 2003. № 12. С. 79.

${ }^{39}$ Мочульська М.С. Правова доктрина та правова наука: співвідношення понять. Проблеми державотворення і захисту прав людини в Україні : матеріали XVIII регіон. наук.-практ. конф. (м. Львів, 26-27 січ. 2012 р.). Львів : Нац. ун-т ім. I. Франка, 2012. C. 39 . 
doctrine pattern, which receives the general recognition of the legal community, which is the basis for legitimizing the doctrine in the public consciousness, the possible official recognition of it by the state (for example, by incorporating a particular doctrinal provision into the text of the law) and the perception of its legal practice.

In connection therewith, it is advisable to give the view of M. M. Korkunov, who believed that when among lawyers on a particular issue formed a fixed view, it necessarily influences the legal practice, which takes into account it in view of scientific authority. Jurisprudence until the relevant view of the communis opinio doctorum is refuted ${ }^{40}$. In this regard, M. E. Mochulska emphasizes that only those scientific statements that are of particular scientific value and are universally recognized in the scientific community become doctrinal ${ }^{41}$. Other important scholars also pay attention to this important feature of legal doctrine.

In addition to the above, M. E. Mochulska proves that, apart from objectification in scientific works (dissertations, monographs, scientific articles, etc.), legal doctrine is embodied in various forms, the characteristics whereof are the required prerequisite for establishing its place and role in the continental legal system. As a result of the analysis of the laws, law-making and law-enforcement practices of the states within this legal system, the researcher finds out the basic forms of expression of legal doctrine, among which the legislative definitions and conclusions of scientific legal expertise deserve special attention. She hereby states that the expression of legal doctrine in the form of legislative definitions is characteristic of most states of the continental legal system (in particular, Germany, Switzerland, France, and Poland) and concludes that the general tendency is the growing role of scientific legal expertise, and therefore the implementation of legal doctrine in the form of expert opinions. Due to the pluralistic approach to the understanding of law in the continental legal system, a general and specific concept of legal doctrine is distinguished.

${ }^{40}$ Коркунов Н.М. Лекции по общей теории права. Изд. 4-е. СанктПетербург : Изд. юрид. кн. магазина Н.К. Мартынова, 1897. 354 c. URL: http://library.nlu.edu.ua/cgibin/irbis64r_01/cgiirbis_64.exe?Z21ID=\&I21DBN=IBIS\&P21DBN=IBIS\&S21STN=1\&S21

$\mathrm{REF}=3 \& \mathrm{~S} 21 \mathrm{FMT}=$ fullwebr $\& \quad \mathrm{C} 21 \mathrm{COM}=\mathrm{S} \& \mathrm{~S} 21 \mathrm{CNR}=20 \& \mathrm{~S} 21 \mathrm{P} 01=0 \& \mathrm{~S} 21 \mathrm{P} 02=0 \& \mathrm{~S} 21 \mathrm{P} 03=$ $\mathrm{M}=\& \mathrm{~S} 21 \mathrm{~S}$ TR $=($ date of access: 28.01.2020).

${ }^{41}$ Мочульська M.Є. Правова доктрина та правова наука: співвідношення понять. Проблеми державотворення і захисту прав людини в Україні : матеріали XVIII регіон. наук.-практ. конф. (м. Львів, 26-27 січ. 2012 р.). Львів : Нац. ун-т ім. І. Франка, 2012. C. 39. 
The first is a legal phenomenon objectified in the form of scientific legal theory developed by scientists to improve positive law; the second (specific) is a traditional and factual source of law, a system of scientific theories, views, concepts, recognized as binding on the scientific legal community and legal practice by sanctioning them by the judiciary and affecting law-making, law-interpreting and law-enforcement processes ${ }^{42}$. The provision that, in a narrow sense, legal doctrine should mean a separate subtype, a particular legal phenomenon that exists in a transitional society is equally important ${ }^{43}$.

There is a reasonable opinion given by I. V. Semenikhin that the doctrinal provisions become generally binding regulations of law, and that the legal doctrine acquires features of a formal source of law only in the case of sanction thereof ${ }^{44}$. With regards thereto, S. S. Aleksieiev hereby emphasizes that the addition of the provisions of the law by the courts results in the fact that in the sphere of law, together with the law, a special regulatory reality appears ${ }^{45}$. The source of this reality, from the point of view of O. O. Zozulia, is the legal doctrine, the most important, basic provisions and conclusions of which do not allow a judge to formulate rules that contradict the essence of law. Under certain circumstances (incomprehensibility, inaccuracy, framework law), the doctrine becomes a real source of law with judicial legitimation ${ }^{46}$.

According to M. M. Voplenko ${ }^{47}$ and V. P. Reutov ${ }^{48}$, the essence of such sanction is in the fact that the state, in the person of its supervisory and regulatory authorities does not deny, but admits with tacit consent or in the most general form recognizes and takes under its own protection of certain rules and regulations.

42 Мочульська М.Є. Правова доктрина в континентальній правовій системі : автореф. дис. ... канд. юрид. наук. Львів, 2011. С. 3-4, 9.

43 Мочульська М.Є. Правова доктрина в континентальній правовій системі : автореф. дис. ... канд. юрид. наук. Львів, 2011. С. 4.

44 Семеніхін І.В. Правова доктрина: загальнотеоретичний аналіз / за ред. О.В. Петришина. Харків : Юрайт, 2012. Вип. 2. С. 55.

45 Алексеев С. С. Право на пороге нового тысячелетия. Некоторые тенденции мирового правового развития - надежда и драма современной эпохи : монография. Москва : Статут, 2000. С. 120.

46 Зозуля А.А. Доктрина в современном праве : дис. ... канд. юрид. наук. СанктПетербург, 2006. С. 171.

${ }^{47}$ Вопленко Н.Н. Источники и формы права : учеб. пособие. Волгоград : Изд-во ВолГУ, 2004. 102 с.

48 Реутов В.П. Типы правопонимания и проблема источников и форм права. Вестник Пермского университета. 2010. № 2 (8). С. 60. 
S. S. Aleksieiev, P. P. Baranov, S. V. Baturin otherwise perceives the legal doctrine, namely as a category of much higher order. In their understanding, it is a complex, integrating category, acting as a kind of model of political and legal reality, legal regulation, reflects the needs of the society, its spiritual and moral foundations, culture, traditions of law and state formation. I. V. Semenikhin also states that the doctrine traditionally related to the position of leading authoritative lawyers, in this sense, serves as a system-forming element, theoretical and methodological foundation of the legal system, state policy in the field of legal regulation, reflects and defines the general model of the latter ${ }^{49}$.

It should be noted that, according to the provisions provided for by the modern procedural laws, "parties to the case are entitled to sue the expert in the field of law regarding the content of the rules of foreign law in accordance with their official or generally accepted interpretation, practice of application, doctrine in the respective foreign state" (para. 2 of Part 1 of Article 112 of the Cassation Arbitration Court of Ukraine) ${ }^{50}$. Identical provisions are contained in the provisions of para. 2 of Part 1 of Article 114 of the Civil Procedure Code of Ukraine ${ }^{51}$, as well as in para. 2 Para 1 of Article 108 of the Commercial Court of Ukraine ${ }^{52}$.

The possibility of the court applying the legal doctrine provided for by the laws of Switzerland, in Article 1 of the Civil Code which the legislator has established the duty of the court to observe the legal doctrine in the administration of justice. Courts of other continental states, including Ukraine, actively use the findings of scientific legal expertise, doctrinal methods of judicial expertise, and comment on regulatory legal acts.

The doctrine is a complex multifaceted legal phenomenon and has a broad functional purpose ${ }^{53}$. Therefore I. S. Zelenkevich attributes it to the

49 Семеніхін І.В. Правова доктрина: загальнотеоретичний аналіз / за ред. О.В. Петришина. Харків : Юрайт, 2012. Вип. 2. С. 18.

${ }^{50}$ Кодекс адміністративного судочинства України : Закон України від 06.07.2005 № 2747-IV. URL: http://zakon2.rada.gov.ua/laws/card/2747-15 (date of access: 27.01.2020).

51 Цивільний процесуальний кодекс України : Закон України від 18.03.2004 № 1618-IV. URL: https://zakon.rada.gov.ua/laws/show/1618-15 (date of access: 27.01.2020).

52 Господарський процесуальний кодекс України : Закон України від 06.11.1991 № 1798-XII. URL: https://zakon.rada.gov.ua/laws/show/1798-12 (date of access: 27.01.2020).

53 Люлькович С.Н. Определение и свойства доктрины (науки) как источника права. Правовая система Республики Беларусь: состояние, проблемы и перспективы развития : материалы IX межвуз. науч. конф. студентов, магистров и аспирантов 
most ancient and mysterious sources of law ${ }^{54}$ From the point of view of S. V. Boshno, it is referred to those legal phenomena which not only repeatedly changed and continue to change the status thereof, but also seek, so to speak, to dissolve in science, jurisprudence, religion, general principles and other forms and sources of law, different phenomena of state-legal reality ${ }^{55}$. Yu. S. Gambarov, who uses the term "law of lawyers" by referring the relevant legal phenomenon paid attention to the aforesaid characteristic feature of legal doctrine, which in his understanding is a symbiosis of legal theory (science) and jurisprudence ${ }^{56}$. In view of this, L. O. Korchevna's approach, which reduces the complex phenomenon of legal doctrine to regulations and principles, should be considered unreasonably narrowed ${ }^{57}$.

Continuing our consideration of the issue, we will point out that the formation of environmental law doctrine in the context of the present requires a prudent approach and a rethinking of the highest social values that are vital, such as: a) human rights (including natural, fundamental, environmental priorities); b) the safety of society as a whole and its component - environmental safety; c) sovereignty of the state (not only as the rule, independence, completeness and indivisibility of power within the territory of the state, independence and equality in external relations, but also as protection of human rights, freedoms and its interests); d) the rule of law, etc.

In addition to the above, it should be remembered that the environmental law doctrine originates from the doctrine of the Soviet era and is related to the doctrine of natural resource, environmental law. By the way, the formation of the Soviet doctrine is related to the names of well-known environmental lawyers, such as: Yu. O. Vovk, O. S. Kolbasov, V. L. Muntian, V. V. Petrov, B. G. Rozovskyi, N. I. Titova et al. In

(г. Гродно, 9 апр. 2009 г.). Гродно : ГрГУ, 2009. С. 196; Романова Е.В. Судебная доктрина в системе источников налогового права США : автореф. дис. ... канд. юрид. наук. Москва, 2012. С. 13; Мадаев Е.О. Доктрина в правовой системе Российской Федерации : дис. ... канд. юрид. наук. Иркутск, 2012. С. 24.

54 Зеленкевич И. С. Правовая доктрина и правовая наука: некоторые аспекты соотношения и использования в качестве источников права. СевероВосточный научный журнал. 2010. № 2 (6). С. 42.

55 Бошно С.В. Доктрина как форма и источник права. Журнал российского права. 2003. № 12. С. 70.

${ }^{56}$ Гамбаров Ю.С. Гражданское право. Общая часть : лекции, прочитан. в Моск. ун-те. Москва : Литогр. Общ. распр. п. кн., 1898. 439-440.

57 Корчевна Л.О. Проблема різноджерельного права: досвід порівняльного правознавства : дис. ... д-ра юрид. наук. Київ, 2005. 412. С. 75-83. 
particular, V. I. Andreitsev believes that the scientific doctrines of environmental law in historical and chronological order can be divided into two varieties: a) scientific doctrines of environmental law of the Soviet era; b) scientific doctrines of the era of independent Ukraine ${ }^{58}$.

It is also worth paying attention to the classification of available doctrinal environmental legal achievements of legal scholars proposed by O. O. Orendarets. Therefore, according to the scientist, we can distinguish the following historical and legal stages of development of science of environmental law: the first is the beginning of the 60's of the twentieth century, distinguished by the emergence of studies of general theoretical problems of land and collective farm law, on the basis of which in the future began to develop the science of environmental law; the second 60 years - the end of the 70's of the twentieth century. It is marked by further scientific researches of the legal protection of the environment and the development of laws on nature protection; the third -80 years - the beginning of the 90's of the 20th century - is a turning point, when new doctrinal approaches to the evolution of environmental law in Ukraine emerge, formation and active development of the doctrine as a holistic complex system of scientific knowledge, and characterized by the expansion of the subject and objects of science of environmental law, the deepening of general theoretical developments and origins substantiation of many environmental concepts; fourth - the end of the 90's of the $20^{\text {th }}$ century and up to this day - it is considered a stage of intensive development of new directions of this science on a qualitatively new basis in the conditions of an independent Ukrainian state, it is marked by a significant expansion of the system of science of environmental law, its subject and objects, which contributes to the emergence of new legal institutions, conceptual scientific developments, etc ${ }^{59}$. As O. O. Orendarets points out, the classification that she proposed is conditional by virtue of the fact it is impossible to determine with the utmost accuracy the moment of the beginning of environmental legal research, and it cannot be clearly stated either when the science of environmental law emerged. The aforementioned classification is based on several criteria: legal, historical, political and subjective. However, the author does not specify which

58 Андрейцев B.I. Наукова доктрина - методологія пізнання та удосконалення екологічного права та практики його застосування. Сучасні науково-практичні проблеми екологічного, земельного та аграрного права : матеріали круглого столу (м. Харків, 6 груд. 2013 р.) / за заг. ред. А.П. Гетьмана. Харків : Право, 2013. С. 12.

59 Орендарець О.О. Розвиток науки екологічного права : автореф. дис. ... канд. юрид. наук. Київ, 2015. С. 10-11. 
scientific studies fall into the doctrinal category. In our opinion, differentiating the latter by four criteria is not quite the right step. At the same time, you can agree with the outlined point of view to some extent.

If we talk about the birth of environmental law doctrine, it would be desirable to distinguish the signs of doctrinal science, their impact on the formation of environmental laws, strategies for the development of state environmental policy, scientific reasonableness (validity) and formal and logical compliance with recognized legal principles. and the regularities of legal science with the possibility of its further legitimation in environmental consciousness, as well as the official recognition by the state as a trend of modern state environmental policy, enshrined in the Law of Ukraine "On the Fundamental Principles (Strategy) of the State Environmental Policy of Ukraine for the Period until 2030" dated February 28, 2019 No. 2697 VIII, the initial position of the Institute of ownership of natural resources related to natural law doctrine, as well as the perception of recent legal practice.

In summary, we can state that the environmental law doctrine should be regarded as a sector legal, that is, as a type of concept in relation to legal doctrine. Given that the purpose of this study was not to classify legal doctrines, but to shed light on some points, it is required to ascertain the relationship between environmental law doctrine. We differentiate the latter into: a) the general doctrine of law; b) the legal doctrine of a particular branch of law, namely environmental law, civil law, etc.; c) the legal doctrine of a separate law institute (sector, inter-branch), including ownership of natural resources.

It should be noted again that the formation of environmental law doctrine is significantly influenced by the European integration processes. According to V. Ya. Tatsiy, there is an urgent need for scientific development of a system of general doctrinal views as a legal ideological basis for the activity of the legislative and executive branches of government in the implementation of the Strategy of integration of Ukraine with the European Union $^{60}$. In turn, A. P. Hetman believes that the goal of legal integration is to unify national legal systems into a single geo-legal space. This process is complex, consisting of several stages, covering: a) deepened interaction and harmonization of principles of formation of the international legal system; b) approximation of national

60 Тацій В.Я. Правова наука та іï завдання щодо забезпечення розвитку громадянського суспільства в Україні. Вибрані статті, виступи, інтерв'ю / упоряд.: О.В. Петришин, Ю.Г. Барабаш, В.І. Борисов. Харків : Право, 2010. С. 539. 
legal systems to international ones, provided that national laws is previously adapted to the legal standards of that system; c) entry of national legal systems into international law and their final adaptation within the single legal space ${ }^{61}$. At the same time, O. D. Tykhomyrov points out that legal space as a concept of legal science has not yet become generally accepted, its interpretation depends on different approaches to legal thinking, philosophical and legal concepts, national legal doctrine, scientific positions of scientists and other factors. Legal space is interpreted as: 1) a way of daily perception of the legal world; 2 ) the concept of legal science, reflecting the diversity of legal phenomena, their relative location and connection or lack thereof; 3 ) together with legal time is an attributive form of existence of legal matter. In modern legal science, legal space is regarded as both an independent legal phenomenon and as a property, a form of existence of other legal phenomena, in particular in the context of the understanding of legal matter, freedom of subjects of law, legal reality, subject of legal regulation, territory of the state or non-state territories and their boundaries, legal acts, legal communication, etc. The scientist believes that due to the "revival" of the spatial approach, such concepts as "social space", "economic space", "environmental space", "and information space" and others have emerged.

Therefore, legal space is of methodological importance in one aspect or another, in one form or another, for any legal research, and not just scientific, of course, recognizing that space is one of the main forms of being of matter ${ }^{62}$. It should be agreed that in the current environment

${ }^{61}$ Гетьман А.П. Сучасний стан та перспективи розвитку еколого-правової науки в Україні. Екологічне право в системі міждисциплінарних зв'язків: методологічні засади : матеріали круглого столу (м. Харків, 4 груд. 2015 р.). Харків : Право, 2015. C. 16.

${ }^{62}$ See: Гнатовський М.M. Європейський правовий простір: Концепція та сучасні проблеми. Київ : Вид. дім “Промені”, 2005. 222 с.; Гнатовський М.М. Становлення та тенденції розвитку європейського правового простору : автореф. дис. ... канд. юрид. наук. Київ, 2002. 22 с.; Гнатовський М.М. Становлення та тенденції розвитку європейського правового простору : дис. ... канд. юрид. наук. Київ, 2002. 193 с.; Кравчук В.М. Філософська площина осягнення правового простору. Актуальні проблеми держави і права. 2011. Вип. 58. С. 63-69; Перчеклій І.М. Право власності українського народу на природні ресурси: еколого-правові засади : автореф. дис. ... канд. юрид. наук. Київ, 2015. 16 с.; Петражицкий Л.И. Введение в изучение права и нравственности. Основы эмоциональной психологии. Санкт-Петербург : Тип. Ю.Н. Эрлих, 1908. 271 с.; Петражицкий Л. И. Теория права и государства в связи с теорией нравственности : в 2 т. Санкт-Петербург : Слово, 1907. Т. 1. 656 с.; 
environmental law space are subject to legal regulation, legal acts and can now become the object of study of environmental law doctrine.

\section{The impact of environmental law doctrine on the state environmental policy formation and the environmental legislation systematization}

In addition to the above, it should be noted that the state environmental policy is a category: a) "dynamic" related to innovative development; b) aimed at satisfying public and private interests; c) functionally linked to other priority areas of public policy; d) implies a plurality of species of subject-object composition; e) it is based on the competitive basis of the use of natural resource potential; f) requires effective economic and legal measures to take advantage of natural resource potential; g) has a longterm character; $h$ ) promotes the modernization of the system of measures for the protection and reproduction of natural resources; i) ensure the improvement of the legal system for environmental policy; j) should aim at achieving international environmental quality standards, etc.

In today's context, state environmental policy should be developed on the basis that the main landmarks of the right to use natural resources should be the conservation of biological and landscape diversity, restoration of environmentally polluted territories, protection and reproduction of natural resources, compliance with environmental security requirements of the population and territories. In view of the above, we give the definition of "state environmental policy" (as a component of state policy) - a system of legal, organizational, economic, social, ideological and other measures of the state, which are taken to preserve nature safe for nature, protection of life and health population, the achievement of harmonious interaction between society and nature, protection, rational use and reproduction of natural resources. However, this is only one side of the problem, because in the formulation of national environmental policy, one should not forget that nowadays national laws, among other things, should be brought into line with EU requirements, and the conclusions set out in the analytical note "Analysis of the Experience of European Cooperation as for the Formation and Implementation of Environmental Policy

\footnotetext{
Тихомиров Д.О. Простір правовий. Велика українська юридична енциклопедія : у 20 т. Т. 2 : Філософія права / редкол.: С.І. Максимов (голова) ; Нац. акад. прав. наук України ; Ін-т держави і права ім. В.М. Корецького НАН України ; Нац. юрид. ун-т ім. Ярослава Мудрого. Харків : Право, 2017. С. 703-707.
} 
Institutions and Instruments" should become the guiding provisions. Therefore, according to this document, the principles of EU environmental policy recognized: 1 ) the principle of subsidiarity (joint action in those areas in which an individual country cannot cope alone, or more coordinated solution of the problem in more than one state); 2) the principle of preventive (preventive) actions; 3 ) the precautionary principle; 4) the principle of compensation for damage to the environment by eliminating the damage at the initial stage of its occurrence; 5) the principle of environmental orientation, when any activity is carried out taking into account the needs of the environment; 6) the polluter pays principle, the effectiveness of which was substantially strengthened in 2004 by Directive 2004/35/EC on civil liability for environmental pollution; 7) the principle of integrating environmental policy into the design and implementation of all other policies $^{63}$.

Furthermore, as it is also stated in the note, due to the trends of the last decades and due to the need to improve and update the environmental policy, the list of environmental protection measures has been expanded. In addition to the adoption of framework laws to ensure a high level of environmental protection, the EU has introduced a number of new instruments (some used in Ukraine): a) LIFE is a financial instrument for environmental protection, its introduction contributes to the development, implementation and updating of environmental policy and laws of the EU; b) environmental agreements, which include obligations to comply with the environmental aspects of the operations of enterprises and the use of methods to encourage the voluntary implementation of environmental measures; c) environmental duties and taxes, that is, the application by Member States of fiscal instruments to improve the effectiveness of environmental policies and ensure their compliance with EU law; d) support programs for NGOs active in the field of environmental protection; e) integrated product policy: The Commission presents a strategy to strengthen and change the focus of production-related environmental policies to promote the market for environmentally friendly products and, ultimately, to stimulate public debate on specific issues; f) the European Environment Agency (through which political resolutionmakers and the public are able to obtain reliable and reliable

63 Аналіз досвіду Європейського співробітництва щодо формування і втілення інституцій та інструментів екологічної політики : аналіт. зап. URL: http://www.niss.gov.ua/articles/840/ (date of access: 28.01.2020). 
environmental information); g) eco-labeling of products (aims at promoting products with reduced environmental impact, compared to other products in the same group); h) the EMAS Environmental Management and Environmental Audit System (EMAS), which is used to improve and improve the environmental performance of European organizations, as well as to provide relevant information to the public and stakeholders; i) environmental impact assessment (EIA) of certain public and private projects; $\mathrm{j}$ ) assessing the environmental impact of the implementation of plans and programs to promote the integration of environmental aspects at the stages of their development and adoption; k) environmental audits by minimum criteria, thereby achieving greater compliance as well as uniformity in the application and implementation of EU environmental laws by providing minimum criteria for the organization, post-control and publication of the results of environmental audits in all Member States; 1) The European Pollutant Release and Transfer Registry (PRTR), which maintains public access to environmental information, which, in turn, prevents or reduces pollution in the long term ${ }^{64}$.

However, the establishment of the essence, content and purpose of environmental law doctrine depends on an understanding of its nature. The idea of filling the concept of "environmental law doctrine" comes by exploring certain approaches to its interpretation. The first is related to the category of "influence", that is, consideration of the relevant systemic influence of natural law doctrine and other ideological factors on environmental consciousness, culture, and way of social life for the formation of stable and deep knowledge, modern legal development of environmental relations.

From the point of view of the second approach, the definition of the concept under study ("environmental law doctrine") is connected and can be considered through the category "function" as a consistent, systematic, directed activity of the state and its organs, public associations, organizations, scientists, aimed at formation of a certain system of environmental knowledge, consciousness, legal understanding of the doctrines, environmental-legal science and state environmental policy. According to O. O. Zozulia, the current state of the legal system requires a fuller use of the law-making potential of the legal doctrine and the

${ }^{64}$ Аналіз досвіду Європейського співробітництва щодо формування і втілення інституцій та інструментів екологічної політики : аналіт. зап. URL: http://www.niss.gov.ua/articles/840/ (date of access: 28.01.2020). 
realization of its basic functions - stabilizing, guiding, heuristic, regulatory, evaluative and predictive ${ }^{65}$.

The proponents of the third approach believe that the environmental law doctrine is formed under the influence of natural law doctrine as a methodological platform and is regarded as a process of positing the provisions of natural law in environmental laws. Like any process, it is characterized by certain content, due to historical, economic, social, ideological, political and environmental factors, has certain components: information, evaluation (formation of values), regulatory, legitimation (necessity of regulations), and organizational ones. In the fourth, the conceptual provisions provided for by the environmental law doctrine is implemented by incorporating the doctrinal provisions into the text of regulatory legal acts or direct reference thereto by taking into account during their adoption by law enforcement authorities, as well as the actual effect of legal doctrine as a form of law.

Based on the concepts of the fifth approach, the adoption of regulatory acts is related to the need to consolidate the principles of environmental law doctrinal provisions of state environmental policy. Therefore, the environmental law doctrine is recognized, i.e. it is due to the reflection of its provisions in the programming documents political, economic and other orientation, regulatory and legal acts, contractual and customary regulations, to resolutions adopted by the public authorities.

\section{CONCLUSIONS}

In view of this, it can be stated that the national environmental law doctrine is a kind of sector legal doctrine, its system-forming element, theoretical and methodological foundation of the legal system, source (form) of environmental law; its basis is the provision of universal scholars of environmentalists who have scientific value and are recognized by the legal community, which serves as the basis for legitimizing the doctrine in the public consciousness, possible official recognition by the state. In addition to the above, based on it, strategic directions of state environmental policy are set, prospects for further development of environmental laws, conceptual approaches to solving environmental problems are introduced and scientifically substantiated, and most importantly, it can be a regulator of public environmental relations. Considering all this, we should add that the main function of the

65 Зозуля А.А. Доктрина в современном праве : дис. ... канд. юрид. наук. СанктПетербург, 2006. С. 11. 
environmental law doctrine should be to promote the creation of a basis for law-making and enforcement. In other words, reflecting the dominant views in the society of representatives of environmental law schools on environmental law, its value and role in the life of the society, environmental law doctrine is a kind of basis for the development of environmental legal regulations, justifies the need and expediency of fixing the law, is an important factor in accelerating the process of becoming law. It has such features as science, consistency, efficiency and stability, etc.

The environmental law doctrine should promote: a) its use in the law-making process, in the development of legal acts and their adaptation to European standards; b) formulation of legislative definitions that will gradually be transformed into an important part of environmental regulations; c) development of the Concept of development of environmental law and laws; d) further codification of environmental laws; e) development of state environmental policy, etc. In the current context of the process of reforming environmental laws, it is advisable to talk about the establishment in the courts of a mechanism for authorizing environmental law doctrine by adopting judgments under the provisions thereof. Natural law doctrine is a significant factor in the ordering of environmental law doctrine, environmental relations, as it is a dynamic category, able to take into account environmental public interests and balance them with the private, and the needs of the society - with the personal environmental needs and rights of citizens.

In view of the foregoing, as well as civilization challenges, Ukraine first needs to activate law-making, modernize environmental law doctrine, relying on concepts which will be revised, relevant provisions of science, state policy, legal understanding and, consequently, law enforcement. It is required to institutionalize the components of environmental law doctrine in the system of environmental laws, which becomes a decisive condition for the further development of statehood and optimization of the rule-making process. The latest philosophical and legal ideas that can positively influence the improvement of the environmental laws (legislative environmental process) should be the basis for that. The environmental law doctrine should become an effective means of harmonizing the system of environmental law and laws, contribute to the definition of the main directions of state environmental policy, and take into account the requirements of the world community and human values. 


\section{SUMMARY}

The influence of environmental law doctrine on the development of state environmental policy and legislation is analyzed in this article. Drawing on methodological approaches, the environmental law doctrine is considered as the branch legal basis of environmental law, state environmental policy, which is institutionalized in environmental legislation and is an integrating set of legal and scientific interpretations and views on law, within which legal forms of cognition of the law and legal phenomena, principles, concepts, terms and constructs are developed, methods, means, techniques of perception, understanding and interpretation of its sources, systems, structures, etc. are substantiated.

The purpose of this article is to consider and to streamline the theoretical and methodological background of the environmental law doctrine formation, to outline perspective directions of establishment and to determine the features of its application in national policy improving, in particular for the environmental legal relations reforming, and further systematization of environmental legislation in the context of European integration and sustainable development, as well as to represent our own vision of this issue.

It is proved that further systematization of environmental legislation should take place on the basis of elaboration of a single scientific doctrine, which will contribute to the correct interpretation of legal norms, overcoming contradictions, collisions and gaps in the current environmental legislation of Ukraine. At the same time, it is concluded that the key task of our country in the context of European integration is to create a coherent, logically agreed national environmental law doctrine as a theoretical basis of the rulemaking processes and to form a single legal space.

\section{REFERENCES}

1. Alekseev S. S. Law on the threshold of a new millennium. Some trends in global legal development - the hope and the drama of the modern era: a monograph. Moscow: Statute, 2000. 256 p.

2. An analysis of the experience of European cooperation in the formulation and implementation of environmental policy institutions and instruments: an analytical note. URL: http://www.niss.gov.ua/articles/840/ (date of access: 01/27/2020).

3. Andreytsev V. I. Environmental law and legislation of sovereign Ukraine: problems of implementation of state environmental policy: Monograph. Dnipro: National mining University, 2011. 373 p. 
4. Andreytsev V. I. Incorporation as an important form of systematization of environmental legislation. Legal Doctrine of Ukraine: Monograph: in 5 vols. Vol. 4: Doctrinal Problems of Environmental, Agrarian and Business Law / Yu. S. Shemshuchenko, A. P. Getman, V. I. Andreytsev, et al. ; for the total. ed. Yu. S. Shemshuchenko. Kharkiv: Pravo, 2013. Subsection 1.4. P. 169-192.

5. Andreytsev V. I. Scientific and scientific-practical schools: status and prospects of legal regulation: monograph. Kiev: Znannya, 2009. $414 \mathrm{p}$.

6. Andreytsev V. I. Scientific doctrine - a methodology of cognition and improvement of environmental law and practice of its application. Modern scientific and practical problems of environmental, land and agrarian law: materials of the round table (Kharkiv, Dec 6, 2013) / for the total. ed. A. P. Getman. Kharkiv: Pravo, 2013. P. 11-14.

7. Anisimova H. V. The influence of the natural-law concept on the development of environmental law doctrine, science and legislation. The level of efficiency and necessity of influence of legal science on rulemaking activity and legal practice: materials of international of scientific-practical conference (Kharkiv, February 5-6, 2016). Kharkiv, 2016. P. 52-55.

8. Baliuk G. I. The role of the environmental law doctrine in the initiation and development of nuclear legal research in Ukraine. Legal Doctrine of Ukraine: Monograph: in 5 vols. Vol. 4: Doctrinal Problems of Environmental, Agrarian and Business Law / Yu. S. Shemshuchenko, A. P. Getman, V. I. Andreytsev, et al. ; for the total. ed. Yu. S. Shemshuchenko. Kharkiv: Pravo, 2013. Subsection 1.7. P. 252-268.

9. Boshno S. V. The Doctrine as a Form and Source of Law. Journal of Russian Law. 2003. № 12. P. 70-79.

10. Gambarov Yu. S. Civil law. General part: lectures, read in Moscow. university. Moscow: Book Distribution Lithographic Society, 1898.766 p.

11. Getman A. P. Current state and prospects of development of environmental-legal science in Ukraine. Environmental law in the system of interdisciplinary communication: methodological foundations: round table materials (Kharkiv, December 4, 2015). Kharkiv: Pravo, 2015. P. 15-27.

12. Getman A. P. Doctrine of Environmental Law and Legislation of Ukraine: Monograph. Kharkiv: "Oberig” LLC, 2019. 336 p. (Kharkiv Scientific School of Environmental Law).

13. Hnatovsky M. M. European legal space: Concept and contemporary problems. Kyiv: Publishing House "Promeni", 2005. 222 p. 
14. Hnatovsky M. M. Formation and tendencies of development of the European legal space: diss. abstract ... cand. of legal sciences. Kyiv, 2002. 22 p.

15. Hnatovsky M. M. Formation and tendencies of development of the European legal space: diss. ... cand. of legal sciences. Kyiv, 2002. 193 p.

16. International Police Encyclopedia: 10 Vol. ed. Yu. I. Rimarenko, Ya. Yu. Kondratiev, V. Ya. Tatsiy, Yu. S. Shemshuchenko. Volume 1: Theoretical and methodological and conceptual principles of police law and police deontology. Kyiv: In Yure, 2003. 1232 p.

17. Karmalita M. V. Legal doctrine - source (form) of law: diss. abstract ... cand. of legal sciences. Kyiv, 2011.21 p.

18. Khabrieva T. Ya. Doctrinal significance of the Russian Constitution. Journal of Russian Law. 2009. No. 2. P. 34-38.

19. Korchevna L. O. The Problem of Multisource Law: The Experience of Comparative Law: Dis. ... Dr. of legal sciences. Kyiv, 2005. 412 p.

20. Korkunov N. M. Lectures on the general theory of law. Ed. 4. St. Petersburg: Ed. legal books shop of N. K. Martynov, 1897. 354 p. URL: http://library.nlu.edu.ua/cgi-bin/irbis64r_01/cgiirbis_64.exe?Z21ID= $\& I 21 \mathrm{DBN}=\mathrm{IBIS} \& \mathrm{P} 21 \mathrm{DBN}=\mathrm{IBIS} \& \mathrm{~S} 21 \mathrm{STN}=1 \& \mathrm{~S} 21 \mathrm{REF}=3 \& \mathrm{~S} 21 \mathrm{FMT}=\mathrm{fu}$ llwebr $\& C 21 \mathrm{COM}=\mathrm{S} \& S 21 \mathrm{CNR}=20 \& S 21 \mathrm{CNR}=20 \& \mathrm{~S} 21 \mathrm{STR}=\quad$ (date of access: 01/27/2020).

21. Kravchuk V. M. Philosophical plane of comprehension of legal space. Actual problems of the state and law. 2011. Iss. 58. P. 63-69.

22.Legal Doctrine of Ukraine: Monograph: 5 volumes. V. 1: General Theoretical and Historical Jurisprudence / V. Ya. Tatsiy, O. D. Svyatotsky, S. I. Maximov, et al.; for the total. ed. O. V. Petryshyn. Kharkiv: Pravo, 2013. 976 p.

23.Legal Doctrine of Ukraine: monograph: in 5 volumes. Vol. 4: Doctrinal problems of environmental, agrarian and commercial law / Yu. S. Shemshuchenko, A. P. Getman, V. I. Andreytsev et al.; for the total. ed. Yu. S. Shemshuchenko. Kharkiv: Pravo, 2013. 848 p.

24. Lyubitenko D. Yu. System features of legal doctrines. Bulletin of the Vladimirskiy Law Institute. 2011. № 1. P. 140-145.

25. Lyulkovich S. N. Definition and features of doctrine (science) as a source of law. The legal system of the Republic of Belarus: state, problems and development prospects: materials of the IX inter-university. scientific conf. of students, masters and graduate students (Grodno, April 9, 2009). Grodno: GrSU, 2009. P. 195-197.

26. Madaev E. O. Doctrine in the legal system of the Russian Federation: dis. ... cand. of legal sciences. Irkutsk, 2012. 254 p. 
27. Maximov S. I. Legal doctrine: philosophical and legal approach. Legal Doctrine of Ukraine: monograph: 5 volumes / ed. V. Ya. Tatsiy, O. D. Svyatotsky, S. I. Maximov [and others]. Volume 1: General Theoretical and Historical Jurisprudence / by general ed. O. V. Petryshyn. Kharkiv: Pravo, 2013. Subsection 1.3. P. 58-93.

28. Mochulska M. E. Legal doctrine and legal science: the relation of concepts. Problems of state formation and protection of human rights in Ukraine: materials XVIII. of scientific-practical conf. (Lviv, January 26-27, 2012). Lviv: I. Franko National university, 2012. P. 39-41.

29. Mochulska M. E. Legal doctrine in the continental legal system: diss. abstract ... cand. of legal sciences. Lviv, 2011. 19 p.

30. On Basic Principles (Strategy) of the State Environmental Policy of Ukraine for the period up to 2030 : Law of Ukraine dated 28.02.2019 № 2697-VIII. URL: https://zakon.rada.gov.ua/laws/show/2697-19 (date of access: 27.01.2020).

31.On Environmental Protection : Law of Ukraine dated 25.06.1991 № 1264-XII. URL: http://zakon5.rada.gov.ua/laws/show/1264-12 (date of access: 27.01.2020).

32. On Higher Education : Law of Ukraine dated 01.07.2014 № 1556-VII. URL: https:// zakon.rada.gov.ua/laws/show/1556-18 (date of access: 27.01.2020).

33. Onishchenko N. M. The legal system: problems of theory: a monograph. Kyiv: V. M. Koretsky Institute of state and law of National Academy of Sciences of Ukraine, 2002. 352 p.

34.On Scientific and Technical Operations : Law of Ukraine dated 26.11.2015 № 848 VIII. URL: http://zakon5.rada.gov.ua/laws/show/848-19 (date of access: 27.01.2020).

35. On the National Research Fund of Ukraine : the Resolution of the Cabinet of Ministers of Ukraine dated 04.07.2018 № 528. URL: http://zakon.rada.gov.ua/laws/show/ru/528-2018-\%D0\%BF (date of access: 27.01.2020).

36. On the Strategy for Sustainable Development "Ukraine-2020" : approved by the Decree of the President of Ukraine dated 12.01.2015 № 5/2015. URL: http://zakon2.rada.gov.ua/ laws/show/5/2015 (date of access: 27.01.2020).

37. Orendarets O. O. Development of the science of environmental law: diss. abstract ... cand. of legal sciences. Kyiv, 2015. 16 p.

38. Parkhomenko N. M. Sources of law: problems of theory and methodology: monograph. Kyiv: Yurid. dumka, 2008. 336 p. 
39. Parkhomenko N. M. System of sources of law: features, properties and content. Journal of the Kyiv University of Law. 2007. № 3. P. 8-12.

40. Perchekliy I. M. The right of property of the Ukrainian people to natural resources: environmental and legal bases: diss. abstract ... cand. of legal sciences. Kyiv, 2015. 16 p.

41. Petrazhitskiy L. I. Introduction to the study of law and morality. Fundamentals of emotional psychology. St. Petersburg: Typ. Yu. N. Erlich, 1908. $271 \mathrm{p}$.

42. Petrazhitskiy L. I. The theory of law and the state in connection with the theory of morality: in 2 volumes. St. Petersburg: Slovo, 1907. T. $1.656 \mathrm{p}$.

43. Puzikov R. V. Legal doctrine in the field of legal regulation (problems of theory and practice): dis. ... cand. of legal sciences. Tambov, 2003.221 p.

44. Reutov V. P. Types of legal understanding and the problem of sources and forms of law. Bulletin of Perm University. 2010. No2 (8). P. 54-70.

45. Romanova E. V. Judicial doctrine in the system of sources of tax law in the USA: diss. abstract ... cand. of legal sciences. Moscow, 2012. $23 \mathrm{p}$.

46. Semenikhin I. V. Legal Doctrine: General Theoretical Analysis / ed. O. V. Petryshyn. Kharkiv: Yurayt, 2012. Vol. 2. 88 p.

47. Skakun O. F. Theory of state and law: a textbook. Kharkiv: Konsum, 2000.704 p.

48. Sorokin V. V. Judicial practice or legal doctrine. Arbitration and civil proceedings. 2002. No. 8. P. 8-11.

49. Tatsiy V. Ya. Legal science and its tasks for ensuring the development of civil society in Ukraine. Selected articles, speeches, interviews / ed. : O. V. Petryshyn, Yu. G. Barabash, V. I. Borisov. Kharkiv: Pravo, 2010. 936 p.

50. The Civil Procedural Code of Ukraine : Law of Ukraine dated 18.03.2004 № 1618-IV. URL: https://zakon.rada.gov.ua/laws/show/161815 (date of access: 27.01.2020).

51. The Code of Administrative Proceedings of Ukraine : Law of Ukraine dated 06.07.2005 № 2747-IV. URL: http://zakon2.rada.gov.ua/ laws/card/2747-15 (date of access: 27.01.2020).

52. The Commercial and Procedural Code of Ukraine : Law of Ukraine dated 06.11.1991 № 1798-XII. URL: https://zakon.rada.gov.ua/laws/ show/1798-12 (date of access: 27.01.2020). 
53. The Great Ukrainian Legal Encyclopedia: in 20 vols. Vol. 3: General Theory of Law / ed.: O. O. Petryshyn (Chairman) [and others]; National Academy of Legal Sciences of Ukraine; V. M. Koretsky Institute of state and law of National Academy of Sciences of Ukraine; Yaroslav Mudryi National Law University. Kharkiv: Pravo, 2017. 952.

54. Theory of state and law: a textbook / O. V. Petryshyn, S. P. Pogrebnyak, V. S. Smorodinsky [and others]; ed. O. V. Petryshyn. Kharkiv: Pravo, 2014. 368 p.

55. Tikhomirov D. O. Legal space. The Great Ukrainian Legal Encyclopedia: in 20 vols. Vol. 2: Philosophy of Law / ed : S. I. Maximov (Chairman); National Academy of Legal Sciences of Ukraine; V. M. Koretsky Institute of state and law of National Academy of Sciences of Ukraine; Yaroslav Mudryi National Law University. Kharkiv: Pravo, 2017. P. 703-707.

56. Trofimenko V. A. In search of an ideal source of law: legal doctrines of the world. Legal advisor. 2007. № 4 (18). P. 82-88.

57. Voplenko N. N. Sources and forms of law: tutorial. Volgograd: VolGU Publishing House, 2004. 102 p.

58.Zelenkevich I. S. Legal doctrine and legal science: some aspects of correlation and usage as sources of law. Northeast Science Journal. 2010. № 2 (6). P. 42-47.

59.Zozulya A. A. The Doctrine in Modern Law: diss. abstract ... cand. of legal sciences. St. Petersburg: St. Petersburg Humanitarian University of Trade Unions, 2006. $31 \mathrm{p}$.

60.Zozulya A. A. The Doctrine in Modern Law: diss. ... cand. of legal sciences. St. Petersburg, 2006. 232 p.

\section{Information about the author: Anisimova H. V., $\mathrm{PhD}$ of Legal Sciences,} Associate Professor at the Environmental Law Department, Yaroslav Mudryi National Law University 